\title{
Applying MERLIN for modelling nitrate leaching in a nitrogen saturated Douglas fir forest in the Netherlands after decreased atmospheric nitrogen input
}

\author{
Albert Tietema, ${ }^{1}$ Bridget A. Emmett ${ }^{2}$ and Bernard J. Cosby ${ }^{3}$ \\ ${ }_{1}$ Netherlands Centre for Geo-Ecological Research (ICG), University of Amsterdam, Nieuwe Prinsengracht 130, 1018 VZ, Amsterdam, The \\ Netherlands, \\ ${ }^{2}$ Institute of Terrestrial Ecology, Bangor Research Unit, Deiniol Road, Bangor, Gwynedd LL.57 2UP, UK, \\ ${ }^{3}$ Department of Environmental Sciences, University of Virginia, Charlottesville, VA, USA 22901.
}

\begin{abstract}
The MERLIN model was applied on the results of a field-scale manipulation experiment with decreased nitrogen (N) deposition in an $\mathrm{N}$ saturated forest ecosystem in The Netherlands. The aim was to investigate the mechanisms that could explain the observed rapid response of nitrate leaching as a result of the decreased $\mathrm{N}$ input. Calibrating the model to pre-treatment data revealed that, despite the high atmospheric $\mathrm{N}$ input, the trees relied on $\mathrm{N}$ mineralised from refractory organic matter (ROM) for their growth. MERLIN could simulate only the fast response of nitrate leaching after decreased input if this ROM mineralisation rate was decreased strongly at the time of the manipulation experiment.
\end{abstract}

\section{Introduction}

As a result of high atmospheric nitrogen $(\mathrm{N})$ inputs in the Netherlands, many of the forest ecosystems are ' $\mathrm{N}$ saturated' (Van Breemen and Van Dijk, 1988; Tietema et al., 1993). As in these ecosystems, the availability of inorganic $\mathrm{N}$ exceeds the total demand of plants and microbes, they are characterised by increased and persistent leaching losses of inorganic $\mathrm{N}$ (mainly nitrate) in groundwater discharge (Aber et al., 1989). As groundwater is one of the major sources for drinking water in the Netherlands, increased nitrate $\left(\mathrm{NO}_{3}\right)$ leaching poses a threat to drinking water quality.

In 1989, as part of NITREX (NITRogen saturation EXperiments) two field-scale manipulation experiments were started in The Netherlands aimed at investigating the reversibility of the effects of $\mathrm{N}$ saturation (Boxman $e t$ al., 1995). NITREX is a consortium of field-scale manipulation experiments with $\mathrm{N}$ deposition in eight countries in north western Europe (Dise and Wright, 1992; Wright and Van Breemen, 1995). At the NITREX sites with relatively high ambient atmospheric $\mathrm{N}$ inputs, including the two Dutch sites, $\mathrm{N}$ deposition was decreased experimentally by intercepting throughfall with a roof underneath the canopy and replacing it with an artificial throughfall solution containing pre-industrial levels of inorganic $\mathrm{N}$ (Boxman et al., 1995). One of the most striking result of this decrease in $N$ inputs was the fast response in soil water $\mathrm{NO}_{3}$ concentrations; $\mathrm{NO}_{3}$ leaching losses. were back to a negligible level within months after the start of the experiment (Boxman et al., 1995; Koopmans et al., 1995; Bredemeier et al., 1998).

Recently, a new model called MERLIN (Model of Ecosystem Retention and Loss of Inorganic Nitrogen) was developed (Cosby et al., 1997). MERLIN is a catchmentscale mass balance model of linked carbon (C) and $N$ cycling, simulating $\mathrm{NO}_{3}$ leaching from forested ecosystems. The model has been tested successfully on the results of a NITREX field-scale $\mathrm{N}$ addition experiment in a Sitka spruce stand in Aber, Wales, UK (Emmett et al., 1997). MERLIN correctly predicted increases in soil water $\mathrm{NO}_{3}$ concentrations in response to increased $\mathrm{N}$ inputs.

Here, MERLIN is applied to the results of the NITREX experiment at Speuld, one of the two NITREX sites in The Netherlands with the aim of investigating the mechanisms that could explain the observed fast response of $\mathrm{NO}_{3}$ leaching to decreased $\mathrm{N}$ input.

\section{Material and methods}

\section{MODEL DESCRIPTION}

MERLIN is described in detail by Cosby et al. (1997) and only a brief description is given here. The structure of 


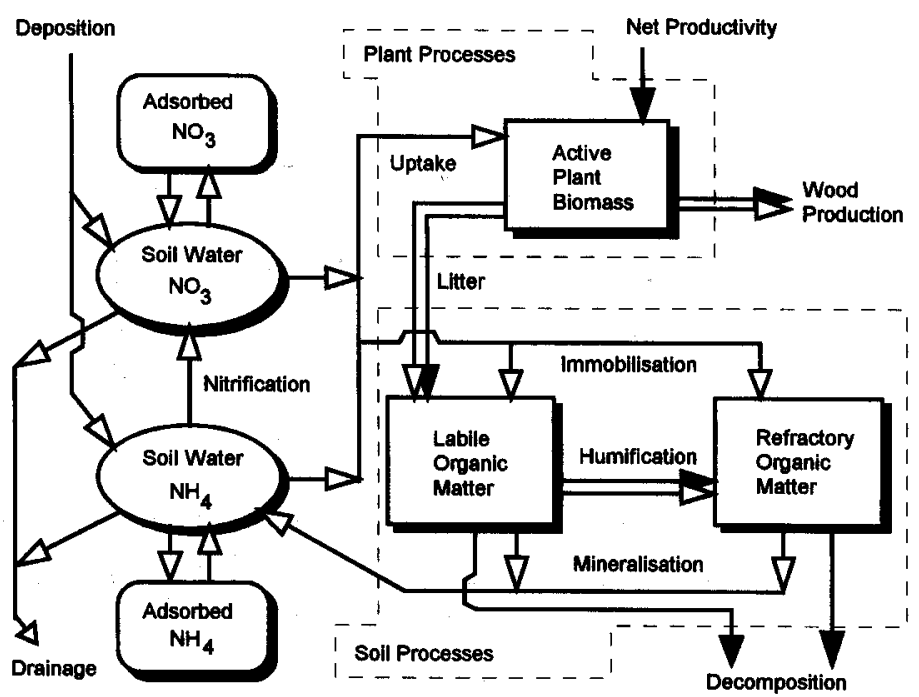

Fig. 1. The conceptual basis of the MERLIN model (Adapted from Cosby et al., 1997). The closed arrows represent $C$ fluxes; the open arrows $N$ fluxes.

MERLIN includes the inorganic soil, a plant compartment and two organic soil compartments (Fig. 1). The plant compartment is an aggregated pool of $\mathrm{C}$ and $\mathrm{N}$ representing the 'active' portion of the vegetation. In forests, this pool conceptually includes, for instance, foliage and fine roots. Wood production can be thought of as long-term storage losses from that pool (Fig. 1). Soil organic material is divided into labile organic matter (LOM) and refractory organic matter (ROM). The LOM pool may be identified as the forest floor, providing a soil organic compartment that responds rather quickly to changing external conditions. The ROM pool represents the bulk of slowly decomposing organic matter in the soil profile down through the A, B and C horizons. Fluxes in and out of the ecosystem and between compartments included in MERLIN are atmospheric deposition, hydrological discharge, plant uptake, litter production, wood production, microbial immobilisation and mineralisation, nitrification and denitrification. Nitrogen fluxes between compartments are controlled by $\mathrm{C}$ productivity, by the $\mathrm{C} / \mathrm{N}$ ratios of organic compartments and by inorganic $\mathrm{N}$ availability in soil solution. MERLIN requires the input of historical sequences of $C$ pools and fluxes, of hydrological discharge, and of external sources of inorganic $\mathrm{N}$, as well as current amounts of $\mathrm{N}$ in the compartments. In addition, it needs parameters specifying plant uptake and microbial immobilisation and soil characteristics such as depth, porosity and bulk density. The output generated by MERLIN includes fluxes of inorganic $\mathrm{N}$ in drainage, total $\mathrm{N}$ contents and $\mathrm{C} / \mathrm{N}$ ratios of the compartments and rates of $\mathrm{N}$ immobilisation (uptake) and mineralisation.

\section{Site description}

The study site is located near Speuld in the central part of the Netherlands $\left(52^{\circ} 13^{\prime} \mathrm{N}, 5^{\circ} 39^{\prime} \mathrm{E}\right)$. The forest stand con- sist of Douglas fir (Pseudotsuga menziesii (Mirb.) Franco.) trees planted in 1962 as two-year old seedlings. The site has a history of oak coppice planted in 1909. This oak coppice was felled in 1960. The soil was neither ploughed nor fertilized before planting the Douglas fir seedlings in 1962 .

At the time of the experiments, tree density was about $800 \mathrm{ha}^{-1}$ and average tree height around $22 \mathrm{~m}$ with no undergrowth present. The forest soil has a $4-7 \mathrm{~cm}$ thick organic layer. The humusform was classified as a mormoder (Green et al., 1993), the soil as a Haplic Podzol (Koopmans et al., 1995) or as a Cambic Podzol (Tiktak et al., 1988). The soil is well-drained, consisting of fluviatile deposits with textures ranging from fine sand to sandy loam. Soil $\mathrm{pH}_{\mathrm{H} 2 \mathrm{O}}$ ranges from 3.7 in the organic layer to 5.1 in the mineral soil. Base saturation in the mineral soil is almost zero. Ground water table is always deeper than $40 \mathrm{~m}$. Atmospheric $\mathrm{N}$ input measured as throughfall in the period from 1985 to 1995 ranged from 40 to $50 \mathrm{~kg} \mathrm{~N} \mathrm{ha}^{-1}$ $\mathrm{y}^{-1}$, about $75 \%$ as ammonium $\left(\mathrm{NH}_{4}\right)$.

Research at the site started in 1985. Two studies have been conducted in the period from 1985 to 1995 .

(1) As part of the Dutch Priority Program on Acidification (DPPA) (1986-1993), the Speuld site was one of the main research sites. During those years an extensive multi-disciplinary inventory was made, yielding a large collection of background data.

(2) The NITREX experiment at Speuld (1989-1995) was carried out within the same stand, but on a different plot as the DPPA study. Starting in 1989, N deposition was decreased experimentally by means of a transparent roof constructed underneath the canopy. The low deposition plot underneath the roof received an artificial throughfall solution with all inorganic nutrients except $\mathrm{N}$ and sulphur (S). A detailed description of the experimental design is given by Boxman et al. (1995). 
Although both studies were carried out on different plots, the results from both studies are utilised for this application of MERLIN to provide as much site specific data as possible for input to the model.

\section{Model input}

\section{Oak coppice (1909-1960)}

The simulations were started as early as 1909 , at the start of the oak coppice rotation. This prevented artificial transients in the pools occurring in 1962 at the time the Douglas fir trees were planted. These transients are likely to result from unbalanced initial conditions. In the simulation of this oak-coppice rotation (1909-1960), all C pools were held constant. The $\mathrm{C}$ and $\mathrm{N}$ pools and fluxes during this rotation were estimated from data from an oak forest called Buunderkamp (Tietema et al., 1993) located in the same area some $50 \mathrm{~km}$ away. This site is characterised as $\mathrm{N}$ limited (Tietema et al., 1993) with relatively low $\mathrm{N}$ deposition for The Netherlands $\left(22 \mathrm{~kg} \mathrm{~N} \mathrm{ha}^{-1} \mathrm{yr}^{-1}\right.$ as throughfall) and with relatively low $\mathrm{NO}_{3}$ leaching ( $7 \mathrm{~kg} \mathrm{~N}$ $\mathrm{ha}^{-1} \mathrm{yr}^{-1}$ ). This low $\mathrm{N}$ status made the site useful for the simulation of the oak coppice rotation at Speuld as it should represent that site in 1960 , before the large increase in $\mathrm{N}$ deposition in this area.

The only dynamics during the oak coppice rotation were caused by a small increase in $\mathrm{N}$ deposition from 1950 to 1960 , coinciding with increased agricultural activity in the area after the second world war. Because the $C$ pools and fluxes were considered constant, $\mathrm{N}$ pools and fluxes changed somewhat due to this increased atmospheric input.

\section{Felling in 1960}

The oak coppice was felled in 1960 . The simulation of this felling with MERLIN was done over two years to prevent negative pools as a result of large changes in pool sizes. The $\mathrm{C}$ storage in plant biomass decreased from standing crop in $1960\left(65 \mathrm{~mol} \mathrm{~m}^{-2}\right)$ to an estimated amount of 10 mol $\mathrm{m}^{-2}$ representing the newly planted young trees in 1962. It was assumed that almost all plant biomass (needles, twigs, branches and fine roots) remained as slash within the ecosystems. As a result, a peak in litter production of $55 \mathrm{~mol} \mathrm{C} \mathrm{m}^{-2}$ was simulated during those two years. It was assumed that the increased input of slash stimulated LOM decomposition temporarily.

Douglas fir (1962-1989)

All the data used for the present-day (1989) characterisation of the Speuld site were collected on the site within DPPA and NITREX, unless otherwise stated.

\section{PRESENT-DAY}

An annual precipitation amount of $800 \mathrm{~mm}$ was used and the water flux below the rooting zone equalled $216 \mathrm{~mm}$ $\mathrm{yr}^{-1}$ (Tiktak and Bouten, 1990). Atmospheric $\mathrm{N}$ input to the ecosystem in 1989 was assumed to be equal to the measured fluxes in throughfall $\left(300 \mathrm{mmol} \mathrm{N} \mathrm{m} \mathrm{yr}^{-1}\right)$. The amount of $\mathrm{N}$ in drainage below the rooting zone amounted to $221 \mathrm{mmol} \mathrm{N} \mathrm{m}^{-2} \mathrm{yr}^{-1}$ (Tietema et al., 1993).

The plant biomass compartment in the Speuld application representing the 'active' part of the tree, consisted of needles, twigs, fine roots and branches. The coarse roots and the stem were considered part of the 'structural' tree compartments or wood production. Current estimates of C and $\mathrm{N}$ in the plant compartments were based on Steingröver and Jans (1995) and Oltshoorn (1991) to give a storage of $159 \mathrm{~mol} \mathrm{C} \mathrm{m}^{-2}$ and $4.9 \mathrm{~mol} \mathrm{~N} \mathrm{~m}^{-2}(\mathrm{C} / \mathrm{N}$ ratio of $\left.32.4 \mathrm{~mol} \mathrm{~mol}^{-1}\right)$ in the active plant biomass and $632 \mathrm{~mol}$ $\mathrm{C} \mathrm{m} \mathrm{m}^{-2}$ and $1.4 \mathrm{~mol} \mathrm{~N} \mathrm{~m}^{-2}$ (C/N ratio of $440 \mathrm{~mol} \mathrm{~mol}^{-1}$ ) in wood.

The organic layer or forest floor was considered to be the LOM pool. In these mormoder humus forms, the organic layer forms a distinct layer of pure organic matter ranging from fresh litter in the L-layer to humified material in the H-layer. In Speuld, however, this H-layer is absent. The total amount of organic matter in this organic layer was $5.5 \mathrm{~kg} \mathrm{~m}^{-2}$ (Tiktak and Bouten, 1990; Tietema, 1993), with mean $C$ and $N$ concentrations of 43 and $2.25 \%$, respectively. This yielded a current total $\mathrm{C}$ and $\mathrm{N}$ storage in LOM of 199 and $8.9 \mathrm{~mol} \mathrm{~m}^{-2}$ respectively, and a C:N ratio of $22 \mathrm{~mol} \mathrm{~mol}^{-1}$.

A soil depth of $100 \mathrm{~cm}$ was taken as a mean rooting depth for this forest. Storage of $\mathrm{C}$ and $\mathrm{N}$ in this top 100 $\mathrm{cm}$ of the mineral soil was considered to represent the ROM pool. The amount was derived from bulk density and concentration data presented by Tiktak et al. (1988) and Van der Maas and Pape (1990) to give a storage of $1280 \mathrm{~mol} \mathrm{C} \mathrm{m}^{-2}$ and $50 \mathrm{~mol} \mathrm{~N} \mathrm{~m}^{-2}$, which resulted in a mean C:N ratio in this pool of $25.2 \mathrm{~mol} \mathrm{~mol}^{-1}$. Litter production in 1989 was $10 \mathrm{~mol} \mathrm{C} \mathrm{m}^{-2} \mathrm{yr}^{-1}$ (Van der Maas and Pape, 1990). The decomposition rate of LOM was calculated at $7.3 \mathrm{~mol} \mathrm{C} \mathrm{m}^{-2} \mathrm{yr}^{-1}$, based on extrapolated litterbag data (Tietema, 1993). The humification rate $(1.9 \mathrm{~mol} \mathrm{C}$ $\left.\mathrm{m}^{-2} \mathrm{yr}^{-1}\right)$ and the ROM decomposition rate $\left(8.4 \mathrm{~mol} \mathrm{C} \mathrm{m}^{-2}\right.$ $\mathrm{yr}^{-1}$ ) in 1989 , followed automatically from the fluxes and the yearly changes in pools on the basis of mass balance. Denitrification was assumed of minor quantitative importance in this well drained soil. An overview of present day (1989) $\mathrm{C}$ and $\mathrm{N}$ pools and fluxes is given in Fig. 2.

\section{HISTORICAL SEQUENCES}

An increase in $\mathrm{N}$ deposition occurred in the early 1950s, coinciding with the start of the massive development of agricultural activity after the second world war. The current (1989) level of $\mathrm{N}$ deposition was assumed to be reached in 1980 (Erisman and Bleeker, 1997) (Fig. 3A). Temporal changes in $\mathrm{C}$ and $\mathrm{N}$ storage in wood and plant biomass (Fig. 3B) were estimated from growth curves for Douglas fir (Jansen et al., 1996). The ratio between C 


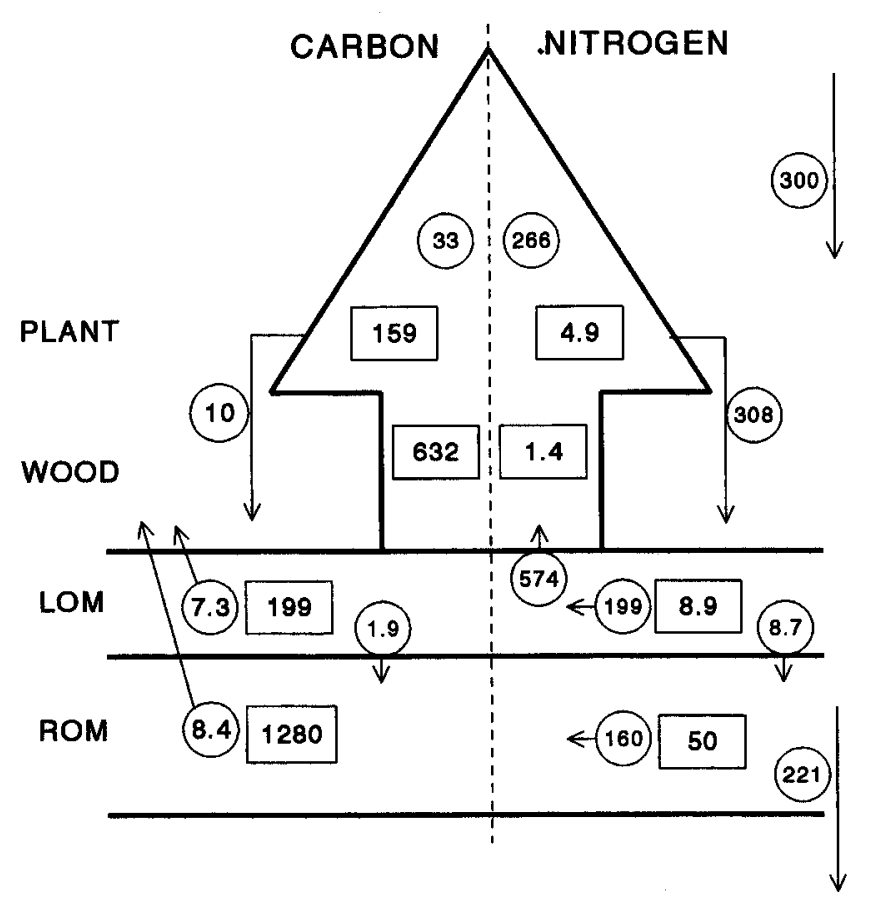

Fig. 2. Pools and fluxes of $C$ and $N$ in the Douglas fir forest at Speuld in 1989. Pools (in mol $\mathrm{m}^{-2}$ ) are shown in boxes with $C$ on the left and $N$ on the right of the dashed line. Fluxes are shomn in circles with $C$ (in mol m$m^{-2} y^{-1}$ ) on the left and $N$ (in mmol m-2 $y r^{-1}$ ) on the right.

storage in plant biomass and wood measured in $1989(0.25)$ was assumed to be constant during the whole period of plant growth. Carbon and N storage in the LOM pool was higher in the Douglas fir forest $\left(199 \mathrm{~mol} \mathrm{C} \mathrm{m}^{-2}\right)$ compared to the oak forest $\left(180 \mathrm{~mol} \mathrm{C} \mathrm{m}^{-2}\right)$. A linear increase in carbon storage in this layer was assumed between the two rotations, except for a small peak between 1963 and 1967 as a result of felling (Fig. 3B). The dynamics of $\mathrm{C}$ stored in ROM was one of the main ways of calibrating the model to the 1989 results, as will be described later. The dynamics of litter production and the decomposition rate of LOM during the early 1960 s were determined largely by felling. Hereafter, both rates increased to a relatively stable level (Fig. 3C).

Besides $\mathrm{N}$ leaching in drainage, $\mathrm{N}$ immobilisation and mineralisation rates in 1989 were used for calibration. Tietema et al. (1993) reported net mineralisation rates at Speuld of 199 and $160 \mathrm{mmol} \mathrm{m}^{-2} \mathrm{yr}^{-1}$ in the forest floor (LOM) and in the top $5 \mathrm{~cm}$ of the mineral soil, respectively. The measured $\mathrm{N}$ mineralisation in this layer was assumed to equal total mineralisation in ROM. A ratio between gross and net mineralisation of 2.4 was used (Tietema and Wessel, 1992; Tietema, 1998) resulting in gross mineralisation and immobilisation rates of 478 and $279 \mathrm{mmol} \mathrm{m}^{-2} \mathrm{yr}^{-1}$ in LOM, and 383 and $223 \mathrm{mmol} \mathrm{m}^{-2}$ $\mathrm{yr}^{-1}$ in ROM. This ratio was measured in the forest floor (LOM) of Speuld and a similar ratio was assumed for ROM.
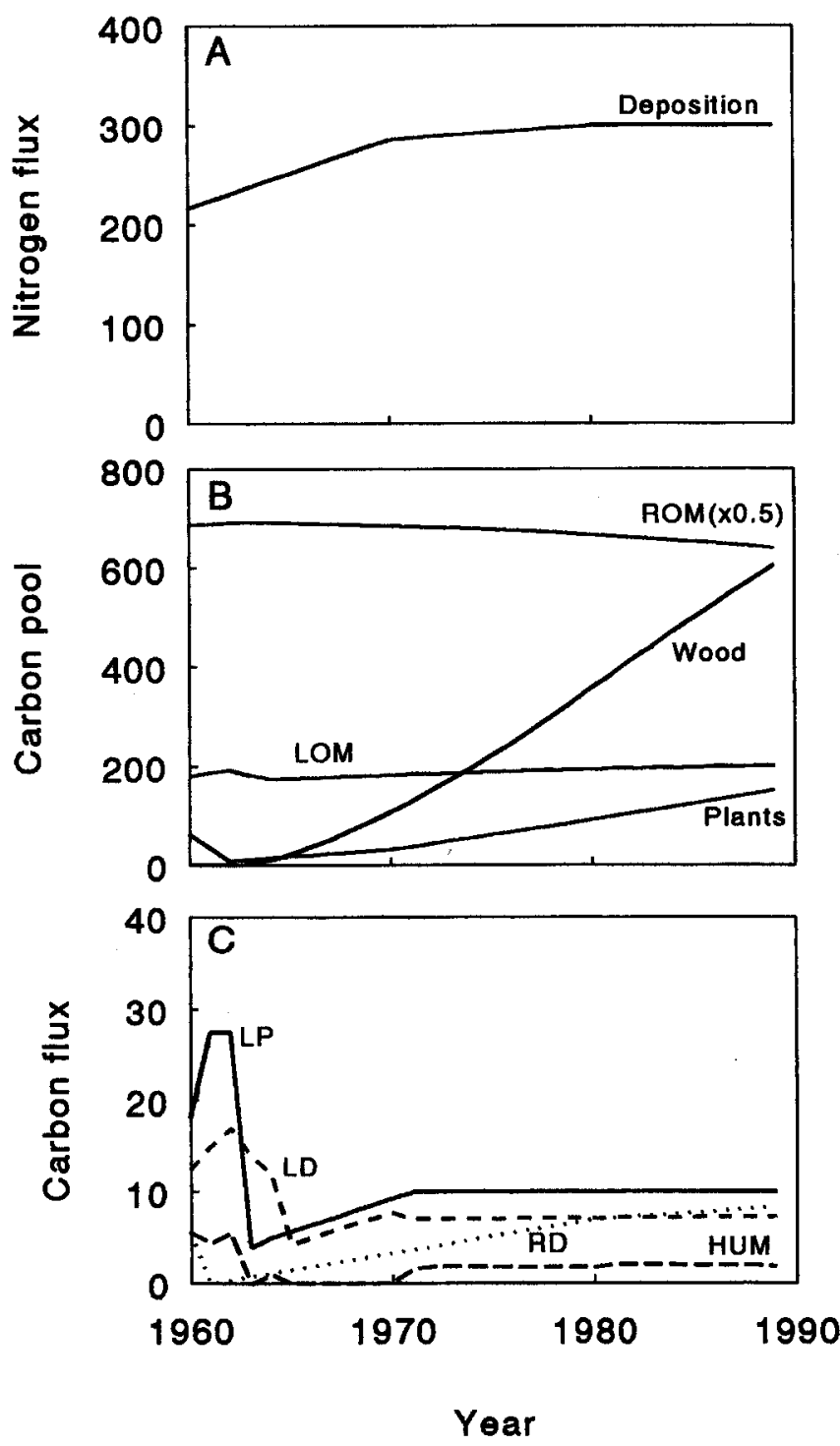

Fig. 3. Sequences of $(A)$ atmospheric $N$ input (in mmol $m^{-2} y r^{-1}$ ), (B) $C$ pools (in mol m-2) and (C) C fluxes (mol m$\left.m^{-2} \mathrm{yr}^{-1}\right)$ used as input for MERLIN in the '1989' calibration.

\section{NITREX experiments (1989-1994)}

From the NITREX experiment, the inorganic $\mathrm{N}$ fluxes in throughfall and drainage measured in the low deposition plot underneath the roof were used for calibration of the model. As a result of the NITREX manipulation, $\mathrm{N}$ input decreased to an average value of $38 \mathrm{mmol} \mathrm{m}^{-2} \mathrm{yr}^{-1}$, about $12 \%$ of the average ambient input (Boxman et al., 1995). This resulted in a $\mathrm{N}$ output by drainage in the period 1990 to 1994 of $73,127,54,7$ and $13 \mathrm{mmol} \mathrm{m}^{-2} \mathrm{yr}^{-1}$, respectively (Boxman et al., 1995).

\section{Calibration and testing}

A comparable trial-and-error calibration procedure, as described by Emmett et al. (1997), run with the assumed 
$\mathrm{C}$ dynamics and deposition history. After comparing simulated $C$ and $N$ pools with the measured values, firstly $C$ dynamics (especially in ROM) were adjusted, and secondly, for further fine-tuning, the $\mathrm{N}$ uptake parameters were adjusted in all organic pools. The definitions of the adjustable uptake parameters used for calibration and explanations for their role within the model are given by Cosby et al. (1997).

The calibration process was achieved in two steps. Firstly, the model was calibrated to match $\mathrm{NO}_{3}$ leaching and $N$ transformations measured in 1989. Secondly, the calibrated parameter set was tested on the results of the NITREX experiments. The main question here was whether the model could successfully predict the fast decrease in $\mathrm{NO}_{3}$ leaching following the reduction in input.

\section{Results and discussion}

\section{Calibration to ' 1989 '}

To meet the $\mathrm{N}$ demand of the tree during the simulation period from 1989 to 1989 and to model the measured output in 1989, an almost linear decrease of C stored in ROM was used, from 1380 to the measured value of $1280 \mathrm{~mol} \mathrm{C}$ $\mathrm{m}^{-2}$ during the thirty years of growth of the Douglas fir trees (Fig. 3B). An overview of $\mathrm{N}$ sinks and sources during that period is given in Table 1 . This means that $\mathrm{N}$ deposition, which is relatively high at this site, is insufficient to supply the trees with enough $\mathrm{N}$. Nitrogen uptake by the canopy was not included as a source in this analysis, which could have made the deficit smaller. This aboveground uptake of $\mathrm{N}$ in coniferous trees, however, would not explain the deficit. Indications for the important role of ROM were found earlier by Emmett et al. (1997) in their MERLIN application at Aber. At Speuld, however, $\mathrm{N}$ inputs are almost three times as high as at Aber.

The distinction between LOM and ROM in MERLIN is conceptual and the separation between these two layers for data input is arbitrary. Nevertheless, the budget of Table 1 clearly shows a large missing source for satisfying

Table 1. Nitrogen sinks and sources (in $\mathrm{mol} \mathrm{N} \mathrm{m}^{-2}$ ) in the Douglas fir forest of Speuld in the period of 1962 to 1989.

\begin{tabular}{lcc}
\hline Compartment & Sink & Source \\
\hline Wood & 1.40 & \\
Plants & 4.53 & \\
LOM & 1.98 & \\
ROM & & 3.90 \\
Soil solution & 0.23 & \\
Adsorbed & 0.01 & \\
Input (1962-1989) & 3.70 & 7.97 \\
Output (1962-1989) & 11.86 & 11.87 \\
Total & & \\
\hline
\end{tabular}

the $\mathrm{N}$ demand for growing trees. Even if the assumptions regarding the increasing LOM is incorrect, there is still a large amount of $\mathrm{N}$ missing which can only originate from the soil.

The general practice in forestry is a sequence of relatively short rotations. Forests are harvested when net growth becomes negligible. In Speuld, this practice would mean that after about 13 rotations the ROM pool would be completely empty as a result of mining by the trees. Obviously this is an exaggeration as Douglas fir stands are not yet harvested at age thirty. In older stands with lower net growth, rates of mining are expected to become much smaller and probably will change in a situation of a net accumulation of $\mathrm{C}$ and $\mathrm{N}$ in ROM. This decreased net $\mathrm{N}$ mineralisation in ROM related to tree age could be regulated by moisture. In older stands, transpiration will be smaller because of decreased tree growth. This could lead to higher moisture contents in the mineral soil and decreased net mineralisation rates due to decreased aeration.

This decreased mining as a result of ageing would also explain how this ROM pool developed after centuries of forest cover. Before the influence of man, forest ecosystems developed along succession sequences. During a climax stage, the total storage of $\mathrm{C}$ and $\mathrm{N}$ in the undisturbed forest ecosystems will have increased slowly as a result of primary production driven by (low) atmospheric $\mathrm{N}$ input and $\mathrm{N}$ fixation. Part of this net input of $\mathrm{C}$ and $\mathrm{N}$ will eventually have been stored in the ROM pool, which explains the current pool of organic matter incorporated in mineral soil.

This mining of ROM for $\mathrm{N}$ was also shown in a MERLIN application on a primary succession of Scots pine on driftsand based on a chronosequence (Tietema, 1997). Between the bare driftsand, and a twenty year old Scots pine stand developed on that driftsand, the $\mathrm{C} / \mathrm{N}$ ratio in ROM increased from about 7 to 11 , while the storage of $\mathrm{C}$ remained almost constant. The amount of $\mathrm{N}$ released from $\mathrm{ROM}$ by this increase in $\mathrm{C} / \mathrm{N}$ ratio, together with the atmospheric input, however, was not sufficient to explain the $\mathbf{N}$ in the twenty year old trees. It was hypothesised that $\mathrm{N}$ fixed by algae in an intermediate succession stage could have accounted for the missing source.

The significance of this mining of the ROM pool by forestry is very difficult to quantify as the changes in pool sizes are very small compared to the absolute pool sizes. In addition, the pool sizes are very difficult to measure with sufficient accuracy. Simulation models like MERLIN should be used to evaluate the significance of this process on a much larger time-scale.

Except for the gross immobilization rate in ROM, the N uptake parameters in the model were calibrated successfully to match observed $\mathrm{N}$ fluxes in 1989 (Table 2). Both $\mathrm{N}$ immobilization and mineralisation rate in ROM are modelled as a function of ROM decomposition rate (Cosby et al., 1997). Immobilization, as all uptake processes in 
Table 2. Nitrogen fluxes (in mol $\mathrm{N} \mathrm{m}^{-2} \mathrm{yr}^{-1}$ ) used for calibration to the situation in 1989 .

\begin{tabular}{lcc}
\hline Flux & Observed & Simulated \\
\hline Leaching & 221 & 221 \\
LOM mineralisation & 478 & 479 \\
LOM immobilization & 279 & 292 \\
ROM mineralisation & 383 & 398 \\
ROM immobilization & 223 & 65 \\
\hline
\end{tabular}

MERLIN, is also dependent on availability of inorganic $N$ in soil solution and on the competitive strength of ROM relative to the other $\mathrm{N}$ sinks. This competitive strength is quantified in two uptake parameters (Cosby et al., 1997; Wright et al., in press). In this application, a combination of ROM decomposition rate and uptake parameters could not be found such that both simulated $\mathrm{N}$ immobilization and mineralisation rates in ROM matched the observed rates. The deviation between observed and simulated immobilization rate can also be the result of an erroneous measurement. The ratio between gross and net mineralisation rate measured by Tietema and Wessel (1992) and Tietema (1998) in LOM was used to calculate gross rates in ROM from a measured net mineralisation rate in ROM. However, this ratio could very well be different in ROM compared to LOM as the microbial population and substrate quality will be completely different in each layers.

The dynamics in $\mathrm{N}$ output in drainage revealed a large peak between 1962 and 1966 as a result of felling (Fig. 4). Maximum $\mathrm{NO}_{3}$ leaching amounted to $420 \mathrm{mmol} \mathrm{N} \mathrm{m}{ }^{-2}$ $\mathrm{yr}^{-1}\left(56 \mathrm{~kg} \mathrm{~N} \mathrm{ha}^{-1} \mathrm{yr}^{-1}\right)$. The large peak is a result of input of slash which, in the first years following felling, changes the micro climate; this can result in a stimulation of the soil mineralisation and nitrification rate (Emmett et al., 1991a). The slash itself can act as a net sink of deposited $\mathrm{N}$ in the early years post-felling (Rosen and LundmarkThelin, 1987). In later years, decomposition of the slash provides an $\mathrm{N}$ supply resulting in continued $\mathrm{NO}_{3}$ leaching. The magnitude and longevity of $\mathrm{NO}_{3}$ leaching relies on the $\mathrm{N}$ status of the site, the input of the slash (absent in whole-tree harvesting) and the extent of regrowth by ground vegetation which acts as a major sink for mineralised N (Emmett et al., 1991b; Stevens et al., 1990).

\section{Application and re-calibration to the NITREX results}

The parameter set calibrated to the '1989' results was used to simulate the NITREX experiments. The results did not show the observed strong decrease in $\mathrm{NO}_{3}$ leaching as a result of the decrease in input (Fig. 5). This fast response suggests a direct coupling of input and output. The $\mathrm{NO}_{3}$ leached in 1989 originated mainly from continuing ROM mineralisation. To get the fast response, the ROM rate decomposition had to be reduced markedly in the period
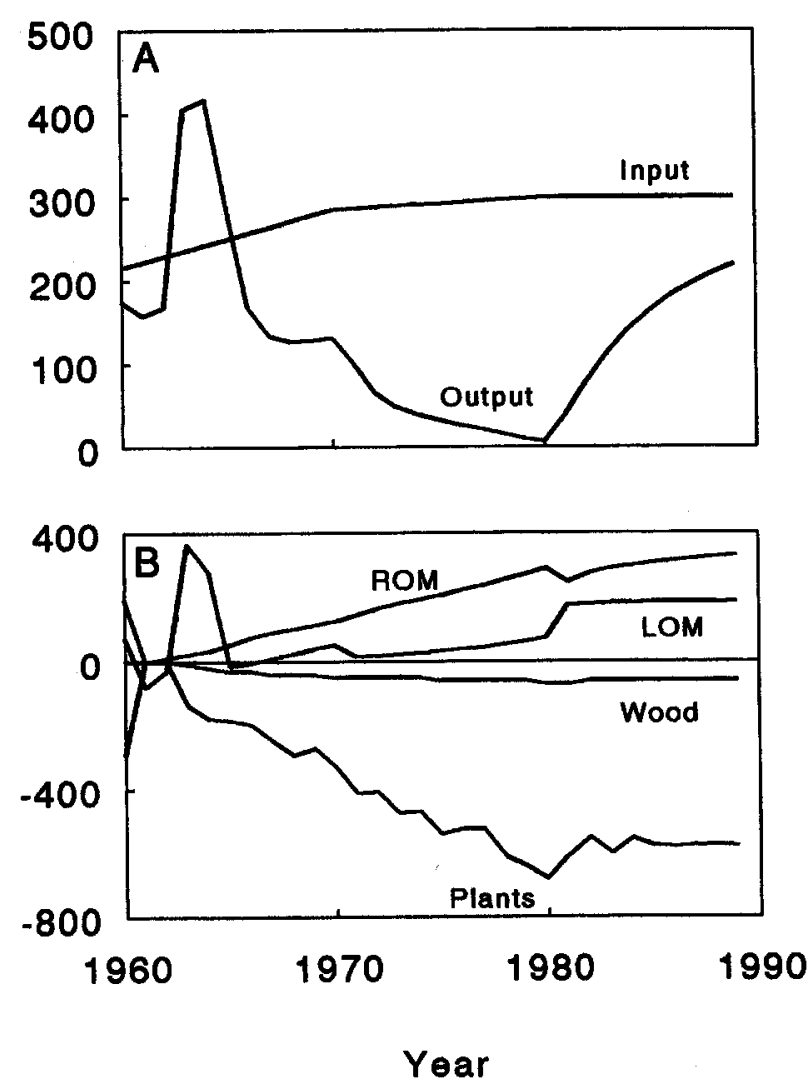

Fig. 4. Nitrogen input and output ( $A$ ) and net assimilation rates in the organic compartments ( $B$ ). All rates are given in mmol $m^{-2}$ $y r^{-1}$. A negative net assimilation rate signifies a net uptake of $N$. The sinks and sources of $N$ in graph $A$ and $B$ do not sum because the inorganic sinks (soil solution and adsorption complex) are not included.

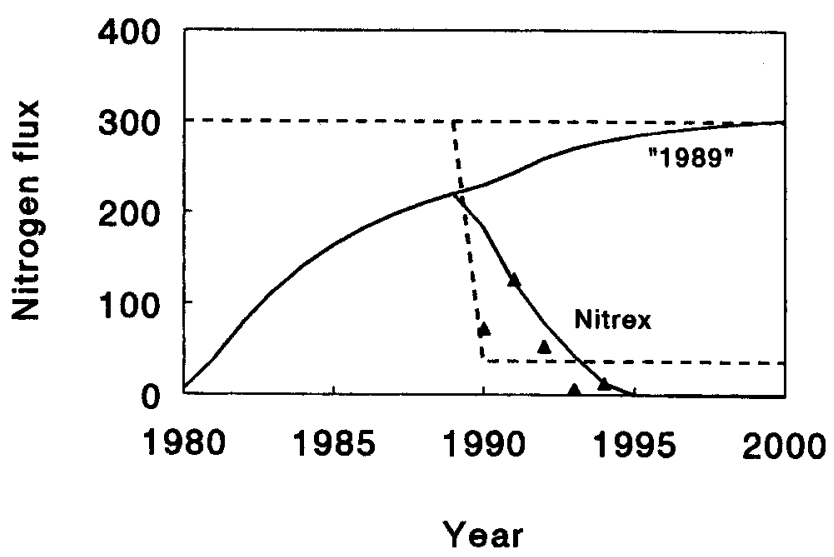

Fig. 5. Nitrogen input (dashed lines) and output (solid lines) of the '1989' and the 'NITREX' run. All rates are given in mmol m-2 $\mathrm{yr}^{-1}$. The points indicate the measured $\mathrm{NO}_{3}$ output in the low deposition plot of the NITREX experiment in Speuld. 
after 1989. With this parameter set, the simulated $\mathrm{NO}_{3}$ leaching agreed well with the observed (Fig. 5).

This decreased decomposition rate of ROM supports the earlier hypothesis that, in older stands, the mining of ROM for $\mathrm{N}$ becomes smaller and probably will change to a situation of a net accumulation of $\mathrm{C}$ and $\mathrm{N}$. The timing of such a change is very difficult to predict. This application of MERLIN on the NITREX experiments at Speuld show that, in a thirty year old Douglas fir stand subjected to high atmospheric $\mathrm{N}$ input, this mining must have become less significant.

\section{Concluding remark}

The applications of MERLIN published to date demonstrate its value clearly for evaluating $\mathbf{N}$ cycling in an ecosystem over a long time period. It can address questions related to the fate (Emmett et al., 1997) and origin (this study) of a supply of $N$. The application of MERLIN at any site requires less site-specific information compared to other process-based models due to its high degree of aggregation in space and time. The model contains compartments intended to be observable and/or interpretable at the plot or catchment scale (Cosby et al., 1997); this makes the model suitable for application at sites where field measurements are generally available.

\section{Acknowledgements}

This work was supported in part by the Commission of European Communities (STEP-CV90-0056, CT93-0264, CT94-0436 and ENV4-CT95-0030), the UK National Environment Research Council, Institute of Terrestrial Ecology, the Research Council of Norway, the Norwegian Institute for Water Research, and the University of Amsterdam.

\section{References}

Aber, J.D., Nadelhoffer, K.J., Streudler, P. and Melillo, J.M., 1989. Nitrogen saturation in northern forest ecosystems. Bioscience, 39, 378-386.

Boxman, A.W., Van Dam, D., Van Dijk, H.F.G., Hogervorst, R.F. and Koopmans, C.J., 1995. Ecosystem responses to reduced nitrogen and sulphur inputs into two coniferous forest stands in the Netherlands. For. Ecol. Manage., 71, 7-29.

Bredemeier, M., Blanck, K., Xu, Y.-J., Tietema, A., Boxman, A.W., Emmett, B.A., Moldan, F., Kjönaas, O.J., Gundersen, P., Schleppi, P. and Wright, R.F., 1998. Input-output budgets at the NITREX sites. For. Ecol. Manage., 101, 57-64.

Cosby, B.J., Ferrier, R.C., Jenkins, A., Emmett, B.A., Wright, R.F. and Tietema, A., 1997. Modelling the ecosystem effects of nitrogen deposition: Model of Ecosystem Retention and Loss of Inorganic Nitrogen (MERLIN). Hydrol. Earth System Sci., 1, 137-158.

Dise, N.B. and Wright, R.F. (Eds) 1992. The NITREX project (Nitrogen saturation experiments). Ecosystem Research Report 2. Commission of the European Communities, Brussels, 101 pp.
Emmett, B.A., Anderson, J.M. and Hornung, M., 1991a. The controls on nitrogen losses following two intensities of harvesting in a Sitka spruce forest (North Wales). For. Ecol. Manage., 41, 81-93.

Emmett, B.A., Anderson, J.M. and Hornung, M., $1991 \mathrm{~b}$. Nitrogen sinks following two intensities of harvesting in a Sitka spruce forest (N. Wales) and the effect on the establishment of the next crop. For. Ecol. Manage., 41, 65-80.

Emmett, B.A., Cosby, B.J., Ferrier, R.C., Jenkins, A., Tietema, A. and Wright, R.F., 1997. Modelling the ecosystem effects of nitrogen deposition: Simulation of nitrogen saturation at a Sitka spruce forest, Aber, Wales, UK. Biogeochemistry, 32, 129-148.

Erisman, J.W. and Bleeker, A., 1997. Emission, concentration and deposition of acidifying substances. In: Acid atmospheric deposition and its effects on terrestrial ecosystems in the Netherlands (G.J. Heij and J.W. Erisman (Eds.)). Studies in Environmental Sciences, 69. Elsevier. Amsterdam, The Netherlands.

Green, R.N., Trowbridge, R.L. and Klinka, K., 1993. Towards a taxonomic classification of humus forms. Forest Science Monograph, 26, 49 pp.

Jansen, J.J., Sevenster, J. and Faber, P.J., 1996. Opbrengsttabellen voor belangrijke boomsoorten in Nederland (in Dutch). IBN rapport 221. IBN-DLO, Wageningen, The Netherlands. 202 pp.

Koopmans, C.J., Lubrechtm W.C. and Tietema, A., 1995. Nitrogen transformations in two nitrogen saturated forest ecosystems subjected to an experimental decrease in nitrogen deposition. Plant Soil, 175, 205-218.

Oltshoorn, A.F.M., 1991. Fine root density and biomass of two Douglas fir stands in The Netherlands. I. Root biomass in early summer. Netherlands 7. Agric. Sci., 39, 49-60.

Rosen, K. and Lundmark-Thelin, A., 1987. Increased nitrogen leaching under piles of slash-a consequence of modern harvesting techniques. Scandinavian 7. Forestry Res., 2, 21-29.

Steingröver, E.G. and Jans, W.W.P., 1995. Physiology of forestgrown Douglas fir trees and effects of air pollution and drought. Dutch Priority Programme on Acidification, report 793315-03, RIVM, Bilthoven, The Netherlands, 84 pp.

Stevens, P.A. and Hornung, M., 1990. Effect of harvest intensity and ground flora establishment on inorganic- $\mathrm{N}$ leaching from a Sitka spruce plantation in North Wales, UK. Biogeochemistry, 10, 53-65.

Tietema, A., 1993. Mass loss and nitrogen dynamics in decomposing litter of five forest ecosystems in relation to increased nitrogen deposition. Biogeochemistry, 20, 45-62.

Tietema, A., 1997. Meten en modelleren van nitraatuitspoeling vanuit bossen op de Velume (in Dutch). Internal Report Nr. 68, Landscape and Environmental Research Group, Amsterdam, The Netherlands. 75 pp.

Tietema, A., 1998. Microbial carbon and nitrogen transformations in litter from coniferous forest ecosystems along an atmospheric nitrogen input gradient. For. Ecol. Manage., 101, 29-36.

Tietema, A., Riemer, L., Verstraten, J.M., Van der Maas, M.P., Van Wijk, A.J. and Van Voorthuysen, I., 1993. Nitrogen transformations in four acid forest soils subject to increased nitrogen deposition. For. Ecol. Manage., 57, 29-44.

Tietema, A. and Wessel, W.W., 1992. Gross nitrogen transformations in the organic layer of acid forest ecosystems subjected to increased atmospheric nitrogen input. Soil Biol. Biochem., 24, 943-950. 